\title{
Egg Mass Density Dependent Parasitoids of Rice Yellow Stem Borer, Scirpophaga incertulas (Walker) (Lepidoptera: Pyralidae)
}

\section{Inakarla Paramasiva ${ }^{1 *}$, Pachipala Rajasekhar ${ }^{1}$, Pinapedda Narasimhulu Harathi ${ }^{1}$, Ummanaboina Vineetha ${ }^{2}$ and Chintala Sreelakshmi ${ }^{3}$}

\author{
${ }^{1}$ Department of Entomology, ${ }^{2}$ Department of Agronomy, ${ }^{3}$ Department of Genetics and Plant \\ breeding, Agricultural Research Station, Nellore, Andhra Pradesh, India
}

*Corresponding author

\section{A B S T R A C T}

K e y w o r d s
Rice stem borer,
$\begin{aligned} & \text { Scirpophaga } \\ & \text { incertulas, } \\ & \text { Parasitoids, } \\ & \text { Tetrastichus, } \\ & \text { Trichogramma, } \\ & \text { Telenomus }\end{aligned}$
Article Info
Accepted:
15 August 2020
Available Online:
10 September 2020

\section{Ke y w o r d s}

Rice stem borer, Scirpophaga incertulas, Parasitoids

Trichogramma

omus
Rice, (Oryza sativa L.), is liable to infestation with several insect pests, from which the rice stem borer, Scirpophaga incertulas (Walker) (Lepidoptera: Pyralidae) is one of the most destructive and widely distributed throughout the india. To determine the extent of parasitization of yellow stemborer egg masses, the egg masses were randomly collected at weekly intervals depending on the availability from rice fields, and brought to the laboratory for collection of emerging parasites. The per cent egg parasitism was calculated based on the emergence of stem borer larvae or adult parasitoids. We found three species of hymenopterous parasitoids-Tetrasticus schoenobii, Telenomus spp., and Trichogramma japonicum from the observations of three consecutive experimental years. Among three, $T$. Shoenobii was predominant and remained active for the longer period as compared to Telenomus sp. and T. Japonicum. In the present study peak activity of T. Shoenobii (73\% in 2015-16; 72.67 in 2016-17 \& 77.33 \% in 2017-18) was found during first week of September, when the stem borer egg mass density was high (1.6 - 5.3 /sq.mt). The yellow stem borer egg parasitoid population followed a linear trend in relation to the availability of the YSB egg masses. Peak activity of Tetrastichus was noted when the egg mass density was high during first week of september, and the Tetrastichus activity was declined with the decrease in stem borer egg mass density.

\section{Introduction}

Rice is one of the important cereal crops of the world and forms staple food for more than 50 per cent of the world population and $85 \%$ Indian population. In India rice is grown over an area of 43.86 million hectares, with a production of 1018.8 million tonnes (Agricultural Statistics at a glance- 2015). In Andhra Pradesh rice is cultivated in about 2.21million hectares with a production of 12.69 million tonnes and productivity of 5.72 t/ ha (Agricultural Statistics at a glance2018). India's rice productivity demeans due to both abiotic and biotic constraints. Among the different insects associated with rice, the yellow stem borer (YSB), Scirpophaga incertulas (Walker) (Lepidoptera: Pyralidae) is one of the most destructive and widely distributed throughout the india (Banerjee, 
1967, Torii, 1967 and Panda, 1976). Its life cycle and nature of damage create complexicities for the control. As an alternative to chemical control or as part of Integrated Pest Management (IPM) programs, there is a resurgence of interest in the use of parasitoids to suppress the S. Incertulas. Early destruction of yellow stem borer egg masses by encouraging the field parasitoid population is essential to maximize yield with least toxic chemical input usage (Gupta et al., 1985). Though, both natural and applied biological control measures are equally important in successful management of pest populations, there has been a shift in emphasis from the introduction of exotic parasites and predators to the recognition of the importance of naturally occurring biological control agents and this approach is gradually becoming one of the major topics in applied entomology (Weber and Lundgren, 2009).

About 60 per cent of the insect-pest control by nature and achieved by the natural enemies. Many workers reported the population regulation of YSB at high density level by the action of egg parasitoids (Pathak, 1968, Nishida and Wongsiri, 1974 and Subba Rao et al., 1983).

Earlier investigations shown that, among the natural enemy complex, egg parasitoids were most predominant than those attacking other developmental stages of yellow stem borer, $S$. Incertulas (Rao, 1972, Israel and Padmanabhan, 1978 and Chandramohan and Chelliah, 1990). Hence, present investigation was carried out to assess the extent of egg parasitism by indigenous egg parasitoids of yellow stem borer, which can become a tool as natural sustaining parasitoids and provident by virtue of their significance in integrated pest management. The natural enemies of YSB and the influence of host density on the abundance of egg parasitoids are discussed in the paper.

\section{Materials and Methods}

Field study was carried out in three consecutive crop years (2015, 2016 and 2017) during Kharif season at Agricultural Research Station, Nellore $\left(14^{\circ} 27^{\prime} \mathrm{N}, 7^{\circ} 59^{\prime} \mathrm{E}, 20 \mathrm{~m}\right.$ above sea level), Andhra Pradesh, India. Soil type in the study area is Red soils/Alluvial soils (PH: 7.9 to 8.1). The mean annual maximum and minimum temperatures are 33.6 and $25.6{ }^{\circ} \mathrm{C}$, respectively with annual precipitation of $1040.7 \mathrm{~mm}$.

The stem borer, S. Incertulas egg masses were collected from pesticide free plots at weekly intervals in a crop season depending upon the availability of egg masses. At each time egg masses were collected at random covering all directions to obtain 100 egg masses. During the egg mass collection process, each egg mass containing leaves were cut of $2 \mathrm{~cm}$ length, the collected egg masses were brought to the laboratory and placed individually in separate plastic vials $(15 \mathrm{~cm}$ long and $2.5 \mathrm{~cm}$ wide) plugged with cotton wool at room temperature $80 \pm 5 \%$ relative humidity and observed periodically for emergence of adult parasitoids.

The parasitoids were emerged from parasitized eggs and the first instar larvae of $S$. Incertulas hatched from un-parasitized eggs, were counted for determination of extent of egg parasitism. Per cent parasitism was computed based on No. of egg masses collected and no.of egg masses from which parasitoids emerged. Parasitoids emerged were identified with the help of key published in the form of booklet (Shepard et al., 1987). The egg parasitism was calculated based on the emergence of larvae or adult parasitoids.

\section{Results and Discussion}

Extent of parasitization of rice yellow stem borer, Scirpophaga incertulas egg masses was 
assessed for three consecutive years (2015-16, 2016-17 and 2017-18) in insecticide untreated rice fields at Agricultural Research Station, Nellore, Andhra Pradesh, India. Our observations confirmed the presence of three species of hymenopteran parasitoids of $S$. Incertulas, namely Tetrastichus shoenobii Ferriere, Telenomus sp. and Trichogramma japonicum Ashmead (Catling 1983, Nickel, 1964). The comparative parasitization by different parasitoids in 2015-16, 2016-17 and 2017-18 is shown in Table 1. The highest level of parasitization was by Tetrastichus wihch ranged from $42.17 \%$ in 2017-18 to $39.54 \%$ in 2016-17. In Bangladesh, Catling (1979) found an average of $75.5 \%$ of egg masses and $49.7 \%$ of eggs were parasitized. T. schoenobii was the most important parasitoid. Catling et al., (1983) reported a similar situation for deepwater rice in Bangladesh, where $61-89 \%$ of yellow stem borer egg masses were parasitized. Tetrastichus schoenobii emerged in a single spell starts from first week of September (24 $\%$ ) and reached peak during $4^{\text {th }}$ week of September $(83 \%)$, parasitisation continued till $4^{\text {th }}$ week of October (Fig. 1). Among naturally occurring egg parasitoids, $T$. Schoenobii was the predominant (Chakraborty, 2012; Chandramohan and Chelliah, 1990) and parasitization by the remaining two parasitoids was less than 10 per cent.

The level of parasitization by Telenomus spp. ranged from 2.79 during 2015-16 and 1.83 during 2017-18 (Table 1). It emerged in one spell starting from $1^{\text {st }}$ week of September $(0.67 \%)$ till October $3^{\text {rd }}$ week $(2 \%)$ peaking in $4^{\text {th }}$ week of September $(6 \%)$ (Fig. 2) (Kumar and Singh, 2016). The level of parasitisation by $T$. japonicum ranged from $3.96 \%$ in 2015-16 and $3.54 \%$ in 2016-17. Parasitization occurred in a single spell starts form $1^{\text {st }}$ week of September $(0.67 \%)$ and continues till $4^{\text {th }}$ week of October $(2 \%)$ and reached peak in $4^{\text {th }}$ week of September $(9 \%)$ (Varma et al., 2013). On the IRRI farm in the Philippines, egg parasitism by T. schoenobii, $T$. rowani, and $T$. japonicum averaged 84,42 and 24 per cent, respectively (Kim et al., 1986).

This might be attributed to the high level of infestation of yellow stem borer on rice during September month (Manju et al., 2002, Hikim 1979) as well as the crop was maintained without any agricultural inputs and free from any pesticidal applications (Mathur, 1999) when the egg masses were kept in vials, large number of parasitoids were emerged rather than the stem borer larvae. These natural enemies particularly egg parasitoids may exert important evolutionary pressure on yellow stem borer and keep the infestation of S. Incertulas under control.

In the present study the periods of parasitoids emergence was form September till October with no emergence in November, December and January, the winter months. This confirms the fact that parasitoids become less active during winter months. Gupta et al., 1985 reported that stem borer egg parasitization by $T$. Schoenobii was high during kharif than Rabi. It was further confirmed by Lakshmi et al., (2010), that $T$. Schoenobii was prevalent from September to November where as Trichogramma and Telenomus from September to October, but the activity of egg parasitoids decreased during November.

High level (47.63\% in 2015-16; $45.95 \%$ in 2016-17 and 48.67 in 2017-18) of cumulative egg parasitization of $S$. Incertulas (Lakshmi et al., 2010; Senapati et al., 1999) emphasized the need to have more truely integrated pest management approached against YSB on rice. This will create opportunities for increased inclusion of biologically base pest management strategies using the three parasitoids (Fig. 3). 
Table.1 Comparative parasitisation by three parasitoid during the periods 2015-16, 2016-17 and 2017-18

\begin{tabular}{|c|c|c|c|c|}
\hline \multirow[t]{2}{*}{ Parasitoid } & \multirow[t]{2}{*}{ family } & \multicolumn{3}{|c|}{ Parasitisation (\%) Mean \pm SD } \\
\hline & & 2015-16 & 2016-17 & 2017-18 \\
\hline Tetrastichus shoenobii & Eulophidae & $40.88 \pm 9.98$ & $39.54 \pm 7.32$ & $42.17 \pm 6.59$ \\
\hline Telenomus spp. & Scelionidae & $2.79 \pm 2.13$ & $2.83 \pm 2.16$ & $1.83 \pm 1.11$ \\
\hline Trichogramma japonicum & Trichogrammatidae & $3.96 \pm 3.07$ & $3.54 \pm 2.66$ & $4.67 \pm 2.66$ \\
\hline $\mathrm{CD}(\mathrm{P}=\mathbf{0 . 0 5 \%})$ & & 7.745 & 7.634 & 9.148 \\
\hline
\end{tabular}

Fig.1 Parasitisation by Tetrastichus shoenobii during the periods 2015-16, 2016-17 and 2017-18

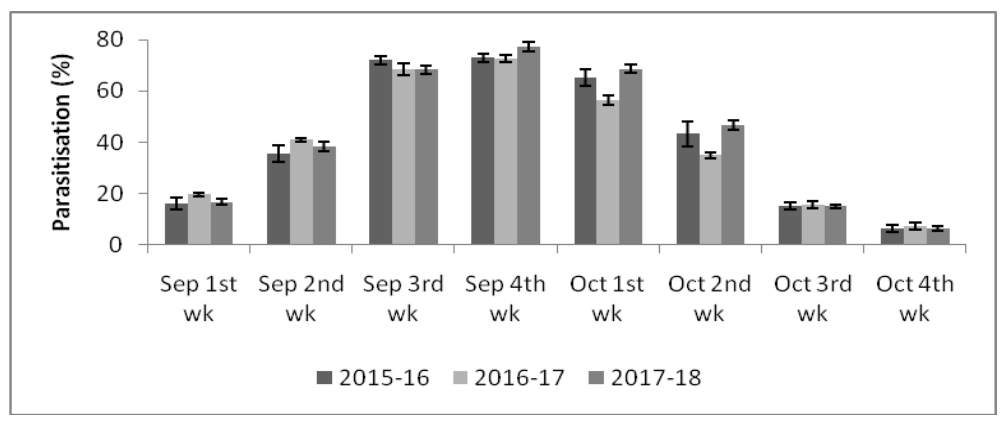

Fig.2 Parasitisation by Telenomus spp. during the periods 2015-16, 2016-17 and 2017-18

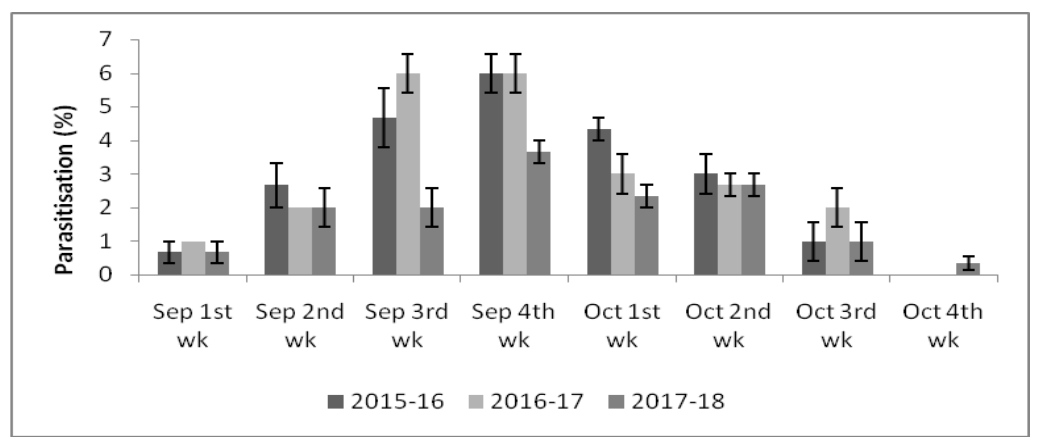

Fig.3 Parasitisation by Trichogramma japonicum during the periods 2015-16, 2016-17 and 2017-18

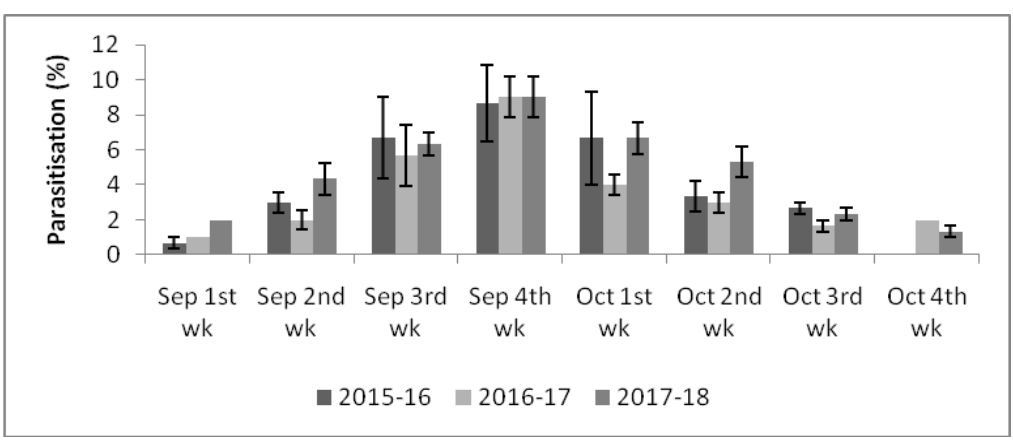


In the present study, peak activity of Tetrastichus was seen during September and October months. The stem borer egg mass density in the above months ranged from 1.6 to 5.3 per square meter with a slow increase in egg mass density from first week of September to $4^{\text {th }}$ week of September followed by decline in the subsequent periods. In the other periods, the egg mass density was from 0.1 to 0.15 per square meter.

The highest $(73 \%$ in $2015-16 ; 72.67 \%$ in 2016-17 and $77.33 \%$ in 2017-18) egg parasitism of Tetrastichus was recorded following the higher egg population in the fourth week of September (Kumar and Singh, 2016). Increased level of Tetrastichus parasitism with corresponding increase in host density was earlier reported by many workers (Rao, 1929; Nickle, 1964; Catling et al., 1983; Kim et al., 1986; Pandya et al., 1995 and Ramanamurthy 2001). Manju et al., 2002 also noted that abundance of egg population was positively correlated with the extent of parasitism.

As reported in many studies, activity of YSB egg parasitoids is seasonally allied, egg mass size dependant, and paddy growth stage specific (Chakraborty, 2012, Shepard and Arida, 1986) and in the present study it was proved, parasitoids acted in a density dependent manner.

Further, it was observed that there was larval survival in egg masses parasitized by $T$. Japonicum but very rarely live larvae were recorded form egg masses parasitized by Telenomus and Tetrastichus. Mostly the egg masses were parasitized either by single or two parasitoid species. Occationally all the three parasitoid species were observed in a single mass. Chakraborty (2012) also reported parasitization of yellow stem borer egg mass by more than one species.
Based on the observations of consecutive experimental years, it is clear that the three parasitoids were prevalent in nature and parasitizing egg masses of $S$. Incertulas. Among three parasitoids, T. Schenobii was found to be predominant as this parasitoid emerged in large number and remained active for the longer period as compared to Telenomus sp. and T. japonicum.

The yellow stem borer egg parasitoid population followed a linear trend in relation to the availability of the YSB egg masses. Peak activity of Tetrastichus was noted when the egg mass density was high during first week of september, and the Tetrastichus activity was declined with the decrease in stem borer egg mass density.

\section{References}

Banerjee, S. N., and Pramanik, L. M. 1967. The lepidoperous stalk borers of rice and their life cyles in the tropics. In The Major Insect Pests of the Rice Plant. Pp. 103-124. Johns Hopkins Press, Baltimore, Maryland, U. S. A.

Chakraborty, K. 2012. Relative composition of egg parasitoid species of yellow stem borer, Scirpophaga incertulas Wlk. In paddy field at Uttar Dinajpur, West Bengal, India. Current Biotica 6(1): 42-52.

Catling, H. D., Islam, Z., and Alam, B. 1983. Egg parasitism of the yellow rice borer, Scirpophaga incertuals (Lep: Pyralidae) in Bangladesh deep water rice. Entomophaga, 28: 227-239.

Chandramohan, N., and Chelliah, S. 1984. Parasite complex of yellow stem borer (YSB). Int. Rice. Res. Newsl. 9(6): 21.

Gupta, M., Chaugule, R. A., and Pawar, A. D. 1985. Role of Tetrastichus schoenobii Ferrierre in controlling yellow rice borer, Scirpophaga incertuals Wlk. Plant Prot Bull. India 37(2): 7-12. 
Hikim, I. S. 1979. Egg parasites of yellow stem borer in West Bengal. Intl. Rice Res. Newsl., 4(5): 451-458.

Hikim, I. S. 1988. Seasonal parasitism by egg parasites of yellow stem borer, Scirpophaga incertulas (Lepidoptera: Pyralidae). Entomologia 33(1): 115124.

Israel, P., and Padmanabhan, S. Y. 1978. Biological control of stem borers of rice in India. Final Technical Report, March 17, 1972-March 16, 1976, U S PL, 480 project, Central Rice Research Institute, Cuttack, India. Pp.155.

Kim, H. S., Keinrics, E. A., and Mylvaganam. P. 1986. Egg parasitism of Scirpophaga incertulas Walker (Lepidoptera: Pyralidae) by hymenopterous parasitoids in International Rice Research Institute rice fields. Korean Journal of Plant Protection. 25(1): 37-40.

Kumar, A., and Singh, A. K. 2016. Extent of egg parasitism of yellow stem borer, Scirpophaga incertulas (Walker) in rice ecosystem. Advances in Life Sciences 5(19): 2278-3849.

Lakshmi, V. J., Surekha, K., and Pasalu, I. C. 2010. Parasitisation of rice yellow stem borer, Scirpophaga incertulas (Walker) egg masses. Annals of Plant Protection Sciences 18 (2): 366-369.

Manju, S., Thangaraju, D., and David, P. M. M. 2002. Relationship among abundance of yellow stem borer moths, egg population and egg parasitism in rice. Intl. Rice Res. Newl., 27(1): 41.

Mathur, K. C., Reddy, P., Rajamani, S., and Moorthy, B. T. S. 1999. Integrated pest management in rice to improve productivity and sustainability. Oryza 36(3): 195-207.

Nickel, J. L. 1964. Biological control of rice stem borers, a feasibility study. International Rice Research Institute, Los Banos, Phillippines, Technical
Bulletin No.2, pp. 111.

Nishida, T., and Wongsiri, T. 1974. Rice stemborer population and biological control in Thailand. College of Tropical Agriculture, Hawaii University, Honolulu, Hawaii, pp. 2537.

Pandya, H. V., Sah, A. H., Patel, C. B., Purohit, M. S., and Rai, A. B. 1995. Study of egg parasitism of rice y ellow stem borer in Gujarat. Gujarat Agricultural University Research Journal 21(1): 197-199.

Pathak, M. D. 1968. Ecology of common insect pest of rice. Ann. Rev. Entimol., 13: 257-294.

Rai, V. P. 1972. Rice stemborers and their natural enemies in India, Pakistan, Ceylon and Malaysia, Mushi, 31: 7-23.

Ram, S., Patnaik, N. C., Sahoo, S., Mohapathra, A. K. B., Samal, K. C., and Meheta, S. 1996. Seasonal activities of egg parasites of Scirpophaga incertulas and extent of parasitism in the Eastern Ghat highland zone of Orissa. Indian J. Entomol. 58 (4): 387-389.

Ramamurthy, V. V. 2001. Exploring the biodiversity and preparation of diagnostic keys for insect and mite fauna in rice crop in India. Final Report I A R I, New Delhi. 155p.

Rao, V. T. 1929. Insect pests and their natural enemies in Circars. Madras agricultural Journal. 17: 373-376.

Senapai, B., and Panda, S. K. 1999. Rice stem borers. In: Insects of cereals and their management. Applied Zoologist Research Association, Cuttack. Pp 169.

Shepard, M., and Arida, G. S. 1986. parasitism and predation of yellow stem borer, Scirpophaga incertulas (Walker) (Lepidoptera: Pyralidae) eggs in transplanted and direct seeded rice. Journal of Entomological Science. 21(1): 26-32. 
Shepard, B. M., Barrion, A. T., and Litsinger, J. A. 1987. Helpful insects, spiders and pathogens. International Rice Research Institute, Los Banos, Laguna, Philippines, 127p.

Subba Rao, C., Venugopal Rao, N., and Razvi, S. A. 1983. Parasitism, a very factor in checking rice pest populations. Entomon. 8: 97-100.

Torii, T. 1967. Statistical methods in rice stemborer research. In "the Major Insect Pests of Rice Plant.” Pp 729. Johns Hopkins Press, Baltimore,
Maryland, U. S. A.

Varma, N. R. G., Jagadeeshswar, R., and Shanker, C. 2013. Relative composition of egg parasitoids of rice yellow stem borer, Scirpophaga incertuals (Walker). Journal of Rice Research. 6(2): 53-58.

Weber, D. C., and Lundgren, J. G. 2009. Assessing the tropic ecology of the Coccinellidae: theri role as predators and as prey. Biological Control 51: 199-214.

\section{How to cite this article:}

Inakarla Paramasiva, Pachipala Rajasekhar, Pinapedda Narasimhulu Harathi, Ummanaboina Vineetha and Chintala Sreelakshmi. 2020. Egg Mass Density Dependent Parasitoids of Rice Yellow Stem Borer, Scirpophaga incertulas (Walker) (Lepidoptera: Pyralidae). Int.J.Curr.Microbiol.App.Sci. 9(09): 1744-1750. doi: https://doi.org/10.20546/ijcmas.2020.909.217 